\title{
School Engagement for Avoiding Dropout in Middle School Education
}

\author{
Cristina Hennig Manzuoli ${ }^{1}$, Clelia Pineda-Báez ${ }^{2}$ \& Ana D. Vargas Sánchez ${ }^{1}$ \\ ${ }^{1}$ Centro de Tecnologías para la Academia, Universidad de La Sabana, Chía, Colombia \\ ${ }^{2}$ Facultad de Educación, Universidad de La Sabana, Chía, Colombia \\ Correspondence: Cristina Hennig Manzuoli, Campus Universitario del Puente del Común, Km. 7, Autopista Norte \\ de Bogotá, Chía, Cundinamarca, Colombia.
}

Received: November 24, 2018

doi:10.5539/ies.v12n5p35

\author{
Accepted: December 30, 2018 \\ Online Published: April 29, 2019 \\ URL: https://doi.org/10.5539/ies.v12n5p35
}

\begin{abstract}
School engagement is a key factor in maintaining school attendance and in diminishing dropout rates. In this study, four dimensions that compose school engagement - cognitive, affective, behavioral, and agentic — were evaluated with a self-report questionnaire (Veiga, 2013), and comparisons between rural and urban schools were made. A total of 802 seventh-graders ( $51.2 \%$ boys and $48.8 \%$ girls), the majority of the studied children were between the ages of 12 and $13(71.7 \%)$, attending public schools in Colombia, responded the questionnaire. The research responds to the need to examine engagement in developing countries. Findings indicate that the cognitive and agentic dimensions obtained the lowest means. This result suggests that students should engage in activities that help them recognize their metacognitive abilities and strengthen their classroom participation. Each of the four identified dimensions is analyzed, and strategies are proposed for developing them appropriately.
\end{abstract}

Keywords: middle school, school engagement, school dropout, student engagement

\section{Introduction}

Various authors have defined school engagement in terms of factors associated with the time and intensity students dedicate to school activities (Kuh et al., 2005; Pascarella \& Terenzini, 2005). This view of school engagement also takes account of school policies and efforts aimed at ensuring student activities and cognitive tasks foster such effort and dedication appropriately and also encourage social participation (Pineda-Báez et al., 2014, p. 4). Ben-David and Ben-Ari (2008) noted that encouraging social participation involves precepts of cognitive constructivism, in that it addresses both the mental activities performed by the student and the collaboration (with all its implications). Thus, engagement is not necessarily an individual task but one that depends to a large extent on collaboration with peers and teachers. These authors add that the understanding of engagement should not be disconnected from the cultures of the students or the professional cultures of the teachers. Clashes between these cultures could affect the proper performance of an academic task. Engagement is varied, complex, and multidimensional (Appleton, Christenson, \& Furlong, 2008); traditionally, it is described in various oppositional terms, such as active/passive, participatory/non-participatory, and interested/disinterested. Generally, engaged students are described as those who demonstrate interest in the learning process (Fredricks, Blumenfeld, \& Paris, 2004), exhibit few disruptive behaviors, socialize with teachers and classmates, and demonstrate willingness and motivation in the learning process. According to Lawson and Lawson (2013) and Montenegro (2017), engagement is malleable; that is, it can be easily modified through the use of active pedagogies. Lawson and Lawson (2013) add that engagement is directly associated with learning and motivation but transcends them to become "energy in action" (Skinner \& Pitzer, 2012, as cited in Lawson \& Lawson, 2013, p. 435).

In the literature, engagement is repeatedly associated with three dimensions. The first is the behavioral dimension, which concerns student participation in academic, social, and extracurricular activities (Fredricks, Blumenfeld, \& Paris, 2004, Lawson \& Lawson, 2013). This type of engagement has been central in the study of obstacles to students' connections with their schools and student disaffection (Henry, Knight, \& Thornberry, 2012). The second dimension is cognitive, which refers to students' psychological investment in academic tasks and their motivation and willingness to learn complex concepts, develop abilities, and increase their use of strategies for the self-regulation of learning, such as memorization and planning (Reeve, 2012; Sheard, Carbone, \& Hurst, 2010; Tomás, Gutiérrez, Sancho, Chireac, \& Romero, 2016). The third is the affective dimension, which involves emotional aspects such as feelings, attitudes, and perceptions of educational environments; the level of affiliation 
with the school; and relationships with classmates and teachers (Appleton, Christenson, \& Furlong, 2008; Archambault, Janosz, Morizot, \& Pagani, 2009; Lawson \& Lawson, 2013).

However, Archambault, Janosz, Morizot, and Pagani (2009) note that there has been little consideration in the literature for how these three dimensions can vary among individuals and over time. Thus, generalizations that fail to consider the heterogeneous characteristics of a given population may well be of limited value. Lawson and Lawson (2013) add that the study of engagement should involve an analysis of the background and experiences of the student both at and outside the school; that is, they should include an environmental dimension that accounts for the influence of peers, family, and other members of the school community on student behavior. This environmental dimension is of substantial importance to student engagement. Reyes, Brackett, Rivers, White and Salovey (2012) have demonstrated that, when classrooms create positive climates through teaching that generates a strong "sense of connection and belonging, enjoyment and enthusiasm, and respect" (p. 8), student engagement and learning are greatly and positively affected. These results agree with those of Raphael, Pressley, and Mohan (2008), who similarly demonstrate that when teachers display authentic and constant concern for their students, they generate conditions that support engagement and learning. As noted by Ramos-Díaz, Rodríguez-Fernández, Fernández-Zabala, Revuelta, and Zuazagoitia (2016), such concern for the student highlights the important role played by teachers and the need for teachers to develop positive relationships with students so that they become more involved in their schoolwork.

To understand the fourth, agentic, dimension, it is necessary to begin by defining personal agency. For Zimmerman and Clearly (2006), personal agency is "one's capacity to originate and direct actions for a given purpose" (p. 45) and is determined by an individual's beliefs regarding their effectiveness and abilities. The agentic dimension refers to students' active involvement in the learning process through the establishment of concrete goals and through proactive, constructive behavior that enriches learning (Lawson \& Lawson, 2013; Montenegro, 2017; Reeve, 2012; Reeve \& Tseng, 2011; Tomás et al., 2016; Veiga, 2013). Proactiveness is demonstrated in the ways that students optimize classroom activities. It is manifested in the suggestions that students make regarding improvements to tasks or exercises, in the questions they ask, in their views regarding their learning needs and those of their peers, in requests for clarifications on questions, or in requests for materials to support their learning (Reeve \& Tseng, 2011). The constructive variable is observed in how student interact with peers to comprehend what is being studied and in their initiatives to interact with teachers (Montenegro, 2017).

Because of its multidimensionality, engagement has been studied from varied perspectives in an attempt to explain its influence on school achievement and success. Archambault, Janosz, Fallu, and Pagani (2009) stress the importance of examining the construct from a holistic perspective. Their results demonstrate that school dropout is linked to school engagement, in which the behavioral component seems a strong predictor of school dropout. Wang and Fedricks (2014) posit that school engagement is linked to problem behavior, which subsequently influences school dropout, and that engagement plays a significant role in students' resilience processes in adapting and coping with the challenges of school. These findings are similar to those of Awang-Hashim, Kaur, and Noman (2015), who suggest that satisfaction, resilience, and purpose in life positively affect adolescents' cognitive school engagement.

Overall, the literature emphasizes that individual, social, and contextual factors influence student engagement. Individual factors include behavior and learning problems that, when combined with particular family and school circumstances, can increase the possibility of school dropout (Fortin, Lessard, \& Marcotte, 2010). Other studies have found that higher levels of school engagement reduce risky health behaviors, such as consumption of illicit substances or poor nutrition (Dolzan, Sartori, Charkhabi \& De Paola, 2015). Likewise, it has been shown that when young students' behavioral and emotional engagement with school decrease, substance consumption and delinquency increase, leading to school abandonment (Henry, Knight, \& Thornberry, 2012; Wang \& Fedricks, 2014). Such problems can be exacerbated if students have to undertake responsibilities such as working to support their families at an early age (Dunne \& Ananga, 2013).

In other cases, identity has been found to influence the way students connect to school, their sense of belongingness, and their opportunities to be part of a community in which they can develop their full academic potential (Jones, Lee, Matlack, \& Zigarelli, 2018). Schools with greater social capital that expose students to behaviors of engagement such as coming to class prepared and completing their homework, as well as continuous reinforcement from highly qualified teachers, seem to positively influence students from different racial and ethnic backgrounds (Ackert, 2018). Other research (Schneider \& Arnot, 2018) proposes communication systems in which data and school information on migrants, points of view, and experiences of parents are available; staff assumptions about migrants and their families; schools' inconsistent strategies with respect to transfer, empowerment of parents; effective feedback loops; and school-level communication policies for migrant parents. 
To successfully implement such systems, schools (like any other organization) must reflect on their communication practices, ensuring that they have addressed the demands and opportunities of an increasingly diverse transnational community and the globally mobile world. All these mechanisms are intended reduce or eliminate the barriers to students' successful engagement with school.

Social and contextual factors also play important roles in student engagement. For example, Schwartz, Stiefel, and Wiswall (2016) report that school size matters, in that schools with fewer students are perceived as offering greater support and providing students with the security required to encourage regular attendance. Relationships with peers also emerge as a critical aspect in long-term school engagement (Ricard \& Pelletier, 2016) and are a predictors for school dropout (Carbonaro \& Workman, 2013). Wang, Kiuru, Degol, and Salmela-Aro (2018) emphasize the strong influence peers exercise on the attitudes, beliefs, values, and behaviors students assume in school. Peers, as agents of socialization, have important effects on students' behavioral, cognitive, and emotional commitment - and, consequently, on academic achievement and success. It is therefore of great importance to look for strategies that can encourage positive changes in adolescents' values and behaviors.

In general, the school environment itself is a decisive factor in determining how students engage with school. Bryant, Shdaimah, Sander and Cornelius (2013) argue that, to overcome problems associated with absenteeism and to encourage attendance and good performance, schools must provide positive environments in which students are treated with respect and are supported as they transition through personal changes. Similarly, Rothman, Buliung, Howard, Macarthur, and Macpherson (2017) observe that schools should be places in which students feel safe. To achieve this, Fortin, Lessard, and Marcotte (2010) argue that dropout prevention programs should focus on teacher attitudes and that schools should foster cooperative environments that include parental participation. Gibbs and Heaton (2014) observe that parental education and employment are key socioeconomic factors that influence students' permanence and engagement at school. More specifically, because the decision to leave school typically results from family factors, the mother's educational level and the father's occupation have become fundamental foci for proposed intervention policies.

Gutiérrez, Tomás, Romero, and Barrica (2017) conducted a study with 2028 Angolan students that concluded support from peers, teachers, and family is concomitant with school engagement, and that family and teachers play key roles in determining students' satisfaction with their school. Fernández-Zabala, Goñi, Camino, and Zulaika (2016) report similar findings from their research on 1543 students in Spain but stress the correlation between teachers' support and student commitment. Quin, Heerde, and Toumbourou (2018) add that teachers are central not only in students' academic and emotional engagement but also in reducing rates of school absenteeism.

Overall, the general trends from studies on student engagement suggest that contextual, as well as individual, factors such as peers, family, and school play vital roles in students' desires to commit to their school experience. However, some studies also emphasize the influence of curriculum on school engagement, noting that it must be aligned with students' perceptions of the real world to emphasize the development of communication skills and collaborative work (Kent, Jones, Mundy, \& Isaacson, 2017). It has also been noted that school experiences should provide the support necessary to facilitate students' transitions between grades and educational levels. Krauss, Kornbluh and Zeldin (2017) find that students' positive experiences outside the school can influence their school involvement. Relationships based on respect with people inside and outside the school community contribute positively to generating students' feelings of affection for the school and promote the desire to remain as part of its community.

There has been notable progress over the past decade in improving Latin American children's access to primary education (Alfonso, Bos, Duarte \& Rondón, 2012; Bassi, Busso, \& Muñoz, 2015). However, despite efforts to guarantee the entrance of higher numbers of children to educational systems and improvements in primary completion rates and in transitions to secondary education, difficulties continue with retaining students at the secondary level (Banco Interamericano de Desarrollo-BID, 2016; Bassi, Busso, \& Muñoz, 2015). Moreover, although data from UNESCO (2013) reveals that Latin American dropout rates decreased from $17.8 \%$ in 2000 to $15.5 \%$ in 2010 , this improvement has not led to significant real-world effects, as Latin American students continue to lag behind their peers in developed countries in terms of achievement (Alfonso, Bos, Duarte, \& Rondón, 2012). Additionally, grade repetition remains a challenge in the majority of Latin American and Caribbean countries. Among the reasons posited for such stagnation are the low quality of education provided to students and deficiencies in the preparation of teachers (UNESCO, 2013).

A limited number of studies have addressed the causes of student dropout at the secondary level in Latin America, particularly in Colombia. Using information from 20,642 children aged 6-17, Rodríguez and Sánchez (2012) find that Colombian students older than 11 tend to drop out of school or join the labor market at early ages due to the 
violence they experience in vulnerable areas of the country. These authors also show that Colombia's armed conflict has accounted for a decrease of $8.78 \%$ in the average years of schooling. Gómez-Restrepo, Padilla, and Rincón (2015) report that dropout rates in Colombia are more pronounced in vulnerable populations, including adolescent single mothers and students in rural areas. However, given the limited number of studies on causes of student dropout in developing nations, such as Colombia, and the importance of increasing access to higher educational levels for national development, the present study sought to analyze school engagement in a group of Colombian seventh-graders. Our work is grounded on the notion that school engagement is fundamental for academic success and that it is related to school dropout rates (Appleton, Christenson, \& Furlong, 2008; Archambault, Janosz, Fallu, \& Pagani, 2009). The present study sought to broaden the analysis of school engagement as mechanism for avoiding dropout in early adolescents, as well as provide a view from Latin America, where few projects of this kind have yet been developed. The questions guiding our research were: What levels of engagement do students show as evaluated by the Student Engagement Scale-4 dimensions (SES-4DS) questionnaire (Veiga, 2013)? Are there significant differences in engagement levels between students at urban and rural Colombian schools? After you have introduced the problem and have developed the background material, explain your approach to solving the problem. In empirical studies, this usually involves stating your hypotheses or specific question and describing how these were derived from theory or are logically connected to previous data and argumentation. Clearly develop the rationale for each. Also, if you have some hypotheses or questions that are central to your purpose and others that are secondary or exploratory, state this prioritization. Explain how the research design permits the inferences needed to examine the hypothesis or provide estimates in answer to the question.

\section{Method}

The present study reports findings from the quantitative phase of the study. This phase sought to establish a baseline for understanding school engagement within a group of 802 seventh-grade pre-adolescents from public schools in Colombia.

\subsection{Participants}

The participants consisted of 802 seventh-grade students (51.2\% boys; $48.8 \%$ girls) at both urban $(57.6 \%)$ and rural (42.3\%) public schools in the neighboring Colombian municipalities of Chía (72.7\%), Cota (12.5\%), and Sopó (14.8\%). The majority of the studied children were between the ages of 12 and 13 (71.7\%).

\subsection{Instrument}

To assess student perceptions of their interest in dedication to school activities, a questionnaire on school engagement by Veiga (2013) was Latin American language adapted and piloted in two groups of students for verify their comprehension. The socio-demographic data captured in the questionnaire included age, gender, sector (rural or urban), and school type (public).

The questionnaire consisted of 20 Likert-type items with five response options. The respondents were asked to indicate the extent to which they were involved in schoolwork and activities. The questions were grouped in four dimensions, each with 5 question items: The cognitive dimension focuses on aspects supporting the learning process, the affective dimension centers on aspects concerning school pertinence and peer support, the behavioral dimension concentrates on behavioral aspects that support learning, and the agentic dimension refers to interaction with teacher and peers to support learning development. The questionnaire achieved a Cronbach's alpha of 0.75

\subsection{Procedure}

This quantitative study complied with all ethical standards appropriate to the field and studies of this kind, including obtaining informed consent from institutional administrations and parents/guardians for work with minors. The questionnaire was administered during February and March of 2018. Written consent to administer the questionnaire was provided by the principal of each participating school. The researchers visited all the public schools in the municipalities of Chía, Cota, and Sopó, Colombia, and the questionnaire was administered by the research team during the school day.

\subsection{Data Analysis}

The data were analyzed with the SPSS 24 software program. First, frequency counts for all the socio-demographic questions and the Likert-scale items were established, in addition to the response percentages, means, and standard deviations for each option. Second, the relationship between the dimensions and the school sector (public or rural) was analyzed, from which the Pearson correlation was calculated. Additionally, means and standard deviations were calculated for each dimension to determine which presented the lowest percentages. 


\section{Results}

\subsection{Dimensions of School Engagement}

Based on the results of the questionnaire on school engagement, the cognitive dimension was the weakest in the groups of surveyed children. In this dimension, the percentage of students who reported writing a first draft of an assignment to organize the text was between $14.1 \%$ and $20.4 \%$ (Table 1 ). This percentage was expected to be higher, which would have indicated that the students were aware of the metacognitive aspects of their learning process. About students' abilities to relate what they learn in one assignment to other assignments, only $38.8 \%$ of students reported always or nearly always doing so (Table 2). With regard to whether students seek additional information on topics discussed in class, only $25.2 \%$ of the students indicated that they spend time doing so (Table 3 ). The aspect that appeared with the greatest frequency was trying to understand what an author is stating in a text. A total of $55.9 \%$ of the students claimed that they always or nearly always do this (Table 4). Regarding reviewing notes before tests, $34.5 \%$ of the students stated that they always or nearly always do this (Table 5).

Table 1. When I do assignments, I write a draft to organize the text

\begin{tabular}{lcccc}
\hline & Frequency & Percentage & $\begin{array}{c}\text { Valid } \\
\text { percentage }\end{array}$ & \begin{tabular}{c} 
Accumulated percentage \\
\hline Occasionally
\end{tabular} \\
Nearly never & 312 & 38.9 & 38.9 & 38.9 \\
Nearly always & 124 & 15.5 & 15.5 & 54.4 \\
Never & 164 & 20.4 & 20.4 & 74.8 \\
Always & 89 & 11.1 & 11.1 & 85.9 \\
Total & 113 & 14.1 & 14.1 & 100.0 \\
\hline
\end{tabular}

Table 2. I try to relate what I learn in one assignment others assignments

\begin{tabular}{lcccc}
\hline & Frequency & Percentage & Valid percentage & $\begin{array}{c}\text { Accumulated } \\
\text { percentage }\end{array}$ \\
\hline Missing data & 3 & 0.4 & 0.4 & 0.4 \\
Occasionally & 300 & 37.4 & 37.4 & 37.8 \\
Nearly never & 120 & 15.0 & 15.0 & 52.7 \\
Nearly always & 210 & 26.2 & 26.2 & 78.9 \\
Never & 68 & 8.5 & 8.5 & 87.4 \\
Always & 101 & 12.6 & 12.6 & 100.0 \\
Total & 802 & 100.0 & 100.0 & \\
\hline
\end{tabular}

Table 3. I spend a lot of free time looking for more information on topics discussed in class

\begin{tabular}{lcccc}
\hline & Frequency & Percentage & Valid percentage & $\begin{array}{c}\text { Accumulated } \\
\text { percentage }\end{array}$ \\
\hline Missing data & 1 & 0.1 & 0.1 & 0.1 \\
Occasionally & 281 & 35.0 & 35.0 & 35.2 \\
Nearly never & 193 & 24.1 & 24.1 & 59.2 \\
Nearly always & 121 & 15.1 & 15.1 & 74.3 \\
Never & 125 & 15.6 & 15.6 & 89.9 \\
Always & 81 & 10.1 & 10.1 & 100.0 \\
Total & 802 & 100.0 & 100.0 & \\
\hline
\end{tabular}


Table 4. When I read a text, I try to understand the meaning the author wishes to convey (i.e., what the author wants to say)

\begin{tabular}{lcccc}
\hline & Frequency & Percentage & Valid percentage & $\begin{array}{c}\text { Accumulated } \\
\text { percentage }\end{array}$ \\
\hline Missing data & 1 & 0.1 & 0.1 & 0.1 \\
Occasionally & 209 & 26.1 & 26.1 & 26.2 \\
Nearly never & 91 & 11.3 & 11.3 & 37.5 \\
Nearly always & 229 & 28.6 & 28.6 & 66.1 \\
Never & 53 & 6.6 & 6.6 & 72.7 \\
Always & 219 & 27.3 & 27.3 & 100.0 \\
Total & 802 & 100.0 & 100.0 & \\
\hline
\end{tabular}

Table 5. I review my notes even when the test is not soon

\begin{tabular}{lcccc}
\hline & Frequency & Percentage & Valid percentage & $\begin{array}{c}\text { Accumulated } \\
\text { percentage }\end{array}$ \\
\hline Occasionally & 258 & 32.2 & 32.2 & 32.2 \\
Nearly never & 159 & 19.8 & 19.8 & 52.0 \\
Nearly always & 174 & 21.7 & 21.7 & 73.7 \\
Missing data & 1 & 0.1 & 0.1 & 73.8 \\
Never & 107 & 13.3 & 13.3 & 87.2 \\
Always & 103 & 12.8 & 12.8 & 100.0 \\
Total & 802 & 100.0 & 100.0 & \\
\hline
\end{tabular}

The affective dimension was the strongest in the groups of surveyed children. In this dimension, the percentage of students who reported that their school is a place where they feel rejected (isolated, secluded) was between $1.6 \%$ and $8.2 \%$ (Table 6). This percentage indicates that they do not sense loneliness and exclusion in their school. Regarding their easiness to make friends in school, only $4.6 \%$ of students reported never making friends (Table 7). Concerning the item that asked whether students felt integrated to school, only $4.9 \%$ of the students indicated that they do not feel included (Table 8 and 9). Only $4.0 \%$ of students reported that the school is a place where their feel alone (Table 10).

Table 6. My school is a place where I feel rejected (isolated, secluded)

\begin{tabular}{lcccc}
\hline & Frequency & Percentage & Valid percentage & $\begin{array}{c}\text { Accumulated } \\
\text { percentage }\end{array}$ \\
\hline Occasionally & 66 & 8.2 & 8.2 & 8.4 \\
Nearly never & 116 & 14.5 & 14.5 & 22.8 \\
Nearly always & 25 & 3.1 & 3.1 & 25.9 \\
Never & 581 & 72.4 & 72.4 & 98.4 \\
Always & 13 & 1.6 & 1.6 & 100.0 \\
Total & 802 & 100.0 & 100.0 & \\
\hline
\end{tabular}

Table 7. My school is a place where I make friends easily

\begin{tabular}{lcccc}
\hline & Frequency & Percentage & Valid percentage & $\begin{array}{c}\text { Accumulated } \\
\text { percentage }\end{array}$ \\
\hline Occasionally & 117 & 14.6 & 14.6 & 14.6 \\
Nearly never & 30 & 3.7 & 3.7 & 18.3 \\
Nearly always & 237 & 29.6 & 29.6 & 47.9 \\
Never & 37 & 4.6 & 4.6 & 52.5 \\
Always & 381 & 47.5 & 47.5 & 100.0 \\
Total & 802 & 100.0 & 100.0 & \\
\hline
\end{tabular}


Table 8. My school is a place where I feel included

\begin{tabular}{lcccc}
\hline & Frequency & Percentage & Valid percentage & $\begin{array}{c}\text { Accumulated } \\
\text { percentage }\end{array}$ \\
\hline Occasionally & 82 & 10.2 & 10.2 & 10.3 \\
Nearly never & 42 & 5.2 & 5.2 & 15.7 \\
Nearly always & 166 & 20.7 & 20.7 & 36.4 \\
Never & 39 & 4.9 & 4.9 & 41.3 \\
Always & 470 & 58.6 & 58.6 & 100.0 \\
Total & 802 & 100.0 & 100.0 & \\
\hline
\end{tabular}

Table 9. My school is a place where I think others appreciate me

\begin{tabular}{lcccc}
\hline & Frequency & Percentage & Valid percentage & $\begin{array}{c}\text { Accumulated } \\
\text { percentage }\end{array}$ \\
\hline Occasionally & 161 & 20.1 & 20.1 & 20.1 \\
Nearly never & 54 & 6.7 & 6.7 & 26.8 \\
Nearly always & 248 & 30.9 & 30.9 & 57.7 \\
Never & 53 & 6.6 & 6.6 & 64.3 \\
Always & 286 & 35.7 & 35.7 & 100.0 \\
Total & 802 & 100.0 & 100.0 & \\
\hline
\end{tabular}

Table 10. My school is a place where I feel alone

\begin{tabular}{lcccc}
\hline & Frequency & Percentage & Valid percentage & $\begin{array}{c}\text { Accumulated } \\
\text { percentage }\end{array}$ \\
\hline Missing data & 1 & .1 & .1 & .1 \\
Occasionally & 82 & 10.2 & 10.2 & 10.3 \\
Nearly never & 121 & 15.1 & 15.1 & 25.4 \\
Nearly always & 39 & 4.9 & 4.9 & 30.3 \\
Never & 527 & 65.7 & 65.7 & 96.0 \\
Always & 32 & 4.0 & 4.0 & 100.0 \\
Total & 802 & 100.0 & 100.0 & \\
\hline
\end{tabular}

The behavioral dimension was strong in the groups of surveyed children. In this dimension, the percentage of students who reported not missing a school day without a justified reason was between $69.2 \%$ and $17.1 \%$ (Table 11). Regarding skipping classes even when the students attend school, a low percentage (1.9\%) reported always doing so (Table 12). Another item asked about interrupting classes on purpose. Only $2.7 \%$ of the students indicated that they interrupt classes persistently (Table 13). A low percentage (2.4\%) of students reported that they are rude to the teachers (Table 14) and only $3.5 \%$ of students feel that they are distracted in the classes (Table 15).

Table 11. I skip school for no justifiable reason

\begin{tabular}{lcccc}
\hline & Frequency & Percentage & Valid percentage & $\begin{array}{c}\text { Accumulated } \\
\text { percentage }\end{array}$ \\
\hline Occasionally & 74 & 9.2 & 9.2 & 9.2 \\
Nearly never & 137 & 17.1 & 17.1 & 26.3 \\
Nearly always & 24 & 3.0 & 3.0 & 29.3 \\
Never & 555 & 69.2 & 69.2 & 98.5 \\
Always & 12 & 1.5 & 1.5 & 100.0 \\
Total & 802 & 100.0 & 100.0 & \\
\hline
\end{tabular}


Table 12. I skip classes even though I am at school

\begin{tabular}{lcccc}
\hline & Frequency & Percentage & Valid percentage & $\begin{array}{c}\text { Accumulated } \\
\text { percentage }\end{array}$ \\
\hline Missing data & 2 & .2 & .2 & .2 \\
Occasionally & 28 & 3.5 & 3.5 & 3.7 \\
Nearly never & 73 & 9.1 & 9.1 & 12.8 \\
Nearly always & 18 & 2.2 & 2.2 & 15.1 \\
Never & 666 & 83.0 & 83.0 & 98.1 \\
Always & 15 & 1.9 & 1.9 & 100.0 \\
Total & 802 & 100.0 & 100.0 & \\
\hline
\end{tabular}

Table 13. I interrupt classes on purpose

\begin{tabular}{lcccc}
\hline & Frequency & Percentage & Valid percentage & $\begin{array}{c}\text { Accumulated } \\
\text { percentage }\end{array}$ \\
\hline Missing data & 1 & .1 & .1 & .1 \\
Occasionally & 99 & 12.3 & 12.3 & 12.5 \\
Nearly never & 193 & 24.1 & 24.1 & 36.7 \\
Nearly always & 37 & 4.6 & 4.6 & 41.3 \\
Never & 449 & 56.0 & 56.0 & 97.3 \\
Always & 22 & 2.7 & 2.7 & 100.0 \\
Total & 802 & 100.0 & 100.0 & \\
\hline
\end{tabular}

Table 14. I am rude to my teachers

\begin{tabular}{lcccc}
\hline & Frequency & Percentage & Valid percentage & $\begin{array}{c}\text { Accumulated } \\
\text { percentage }\end{array}$ \\
\hline Missing data & 2 & .2 & .2 & .2 \\
Occasionally & 57 & 7.1 & 7.1 & 7.4 \\
Nearly never & 104 & 13.0 & 13.0 & 20.3 \\
Nearly always & 40 & 5.0 & 5.0 & 25.3 \\
Never & 579 & 72.2 & 72.2 & 97.6 \\
Always & 19 & 2.4 & 2.4 & 100.0 \\
Total & 802 & 100.0 & 100.0 & \\
\hline
\end{tabular}

Table 15. I am distracted in class

\begin{tabular}{lcccc}
\hline & Frequency & Percentage & Valid percentage & $\begin{array}{c}\text { Accumulated } \\
\text { percentage }\end{array}$ \\
\hline Missing data & 2 & .2 & .2 & .2 \\
Occasionally & 199 & 24.8 & 24.8 & 25.1 \\
Nearly never & 258 & 32.2 & 32.2 & 57.2 \\
Nearly always & 64 & 8.0 & 8.0 & 65.2 \\
Never & 250 & 31.2 & 31.2 & 96.5 \\
Always & 28 & 3.5 & 3.5 & 100.0 \\
Total & 802 & 100.0 & 100.0 & \\
\hline
\end{tabular}

Regarding the agentic dimension, students reported that they never, nearly never, or occasionally $(62.5 \%)$ ask the teachers questions (Table 16$)$ and that they never or nearly never $(59.8 \%)$ speak with teachers (Table 17$)$. This dimension should also be addressed with younger children and, in a later phase of the study, with teachers, because communication between the two groups appeared limited, and this could affect students' learning process. 
Table 16. During class, I ask the teachers questions

\begin{tabular}{lcccc}
\hline & Frequency & Percentage & Valid percentage & $\begin{array}{c}\text { Accumulated } \\
\text { percentage }\end{array}$ \\
\hline Missing data & 3 & 0.4 & 0.4 & 0.4 \\
Occasionally & 350 & 43.6 & 43.6 & 44.0 \\
Nearly never & 106 & 13.2 & 13.2 & 57.2 \\
Nearly always & 197 & 24.6 & 24.6 & 81.8 \\
Never & 46 & 5.7 & 5.7 & 87.5 \\
Always & 100 & 12.5 & 12.5 & 100.0 \\
Total & 802 & 100.0 & 100.0 & \\
\hline
\end{tabular}

Table 17. I talk to my teachers about what I like and don't like

\begin{tabular}{lcccc}
\hline & Frequency & Percentage & Valid percentage & $\begin{array}{c}\text { Accumulated } \\
\text { percentage }\end{array}$ \\
\hline Missing data & 1 & 0.1 & 0.1 & 0.1 \\
Occasionally & 165 & 20.6 & 20.6 & 20.7 \\
Nearly never & 213 & 26.6 & 26.6 & 47.3 \\
Nearly always & 106 & 13.2 & 13.2 & 60.5 \\
Never & 266 & 33.2 & 33.2 & 93.6 \\
Always & 51 & 6.4 & 6.4 & 100.0 \\
Total & 802 & 100 & 100 & \\
\hline
\end{tabular}

\subsection{Relationship Between Dimensions of School Engagement}

The results demonstrate that the dimensions with the lowest percentages were the cognitive dimension (3.14\%) and the agentic dimension $(2.87 \%)$. These outcomes indicate that these factors require reinforcement in the surveyed population.

Table 18. Means and standard deviations according to the 4 dimensions

\begin{tabular}{lcc}
\hline Dimensions & Mean & Standard Deviation \\
\hline Cognitive & 3.136 & 1.174 \\
Affective & 4.20 & 1.062 \\
Behavioral & 4.56 & 0.656 \\
Agentic & 2.87 & 1.230 \\
\hline
\end{tabular}

\subsection{Relationship Between the Zone (Urban and Rural) and Dimensions of School Engagement}

The data demonstrate that the zone in which a school is located does not affect school engagement among participating students. The Pearson correlations obtained values far from 1 (Table 19). 
Table 19. Correlations between school zone (urban and rural) and dimensions $(\mathrm{N}=802)$.

\begin{tabular}{|c|c|c|}
\hline Cognitive Dimension & Correlation & Standard Error \\
\hline $\begin{array}{l}\text { [When I do assignments, I write a draft to organize } \\
\text { the text.] }\end{array}$ & 0.002 & 0.035 \\
\hline $\begin{array}{l}\text { [I try to relate what I learn in one assignment to other } \\
\text { assignments.] }\end{array}$ & 0.042 & 0.035 \\
\hline $\begin{array}{l}\text { [I spend a lot of free time looking for more } \\
\text { information on topics discussed in class.] }\end{array}$ & 0.069 & 0.036 \\
\hline $\begin{array}{l}\text { [When I read a text, I try to understand the meaning } \\
\text { the author wishes to convey (what the author wants to } \\
\text { say).] }\end{array}$ & 0.104 & 0.035 \\
\hline [I review my notes even when the test is not soon.] & -0.017 & 0.036 \\
\hline Affective Dimension & Correlation & Standard Error \\
\hline $\begin{array}{l}\text { [My school is a place where I feel rejected (isolated, } \\
\text { separated.] }\end{array}$ & -0.028 & 0.036 \\
\hline [My school is a place where I make friends easily.] & -0.124 & 0.035 \\
\hline $\begin{array}{l}\text { [My school is a place where I feel included (accepted, } \\
\text { that I am part of the school).] }\end{array}$ & -0.087 & 0.036 \\
\hline $\begin{array}{l}\text { [My school is a place where I feel that others } \\
\text { appreciate me.] }\end{array}$ & -0.107 & 0.035 \\
\hline [My school is a place where I feel alone.] & -0.102 & 0.035 \\
\hline Behavioral Dimension & Correlation & Standard Error \\
\hline [I skip school for no justifiable reason.] & -0.026 & 0.036 \\
\hline [I skip classes even though I am at school.] & -0.151 & 0.032 \\
\hline [I interrupt classes on purpose (intentionally).] & -0.065 & 0.035 \\
\hline [I am rude to my teachers.] & -0.116 & 0.034 \\
\hline [I am distracted in class. $]$ & 0.041 & 0.036 \\
\hline Agentic Dimension & Correlation & Standard Error \\
\hline [During class, I ask the teachers questions.] & 0.154 & 0.035 \\
\hline $\begin{array}{l}\text { [I talk to my teachers about what I like and don't } \\
\text { like.] }\end{array}$ & 0.155 & 0.035 \\
\hline $\begin{array}{l}\text { [When something interests me, I mention it to my } \\
\text { teachers.] }\end{array}$ & 0.038 & 0.035 \\
\hline [During class, I participate to express my opinions.] & 0.039 & 0.036 \\
\hline $\begin{array}{l}\text { [I make suggestions to my teachers about how to } \\
\text { improve class.] }\end{array}$ & 0.121 & 0.035 \\
\hline
\end{tabular}

\section{Discussion and Conclusions}

The purpose of the present study was to identify the dimensions that negatively affect school engagement among seventh-grade students in public schools in several neighboring Colombian municipalities. The results show that the cognitive and agentic dimensions at the schools that participated in this study require special attention. Therefore, it would be appropriate to consider proposals, such as those presented by Kent, Jones, Mundy, and Isaacson (2017), that seek to make the educational contexts at these schools more closely reflect real-world circumstances.

Trying to relate what has been learned in one assignment to another assignment, spending a substantial amount of free time seeking more information on topics discussed in class, writing drafts to organize texts, or trying to understand the meaning of a text after reading it were actions that students stated they do not perform frequently. This outcome indicates that the psychological investment in academic activities that involve analysis, synthesis, and planning (Reeve, 2012; Sheard, Carbone, \& Hurst, 2010; Tomás, Gutiérrez, Sancho, Chireac, \& Romero, 2016) is low. Therefore, schools must work on helping students discover strategies that help them to self-regulate their learning process (Tomás, Gutiérrez, Sancho, Chireac, \& Romero, 2016).

In the agentic dimension, it was expected that students participate in class and make suggestions to achieve learning objectives (Zimmerman \& Clearly, 2006). However, the present study found that this dimension was not strong among the surveyed participants, based on the behaviors that students indicated they do not exhibit in the 
classroom, such as asking questions during class, engaging in conversations with teachers to express opinions, or making suggestions for improvements. This outcome reinforces the notion that the agentic dimension is closely related to the school environment. Thus, teachers should seek to strengthen student participation and decision-making as suggested in previous studies (Bryant, Shdaimah, Sander, \& Cornelius, 2013; Carbonaro \& Workman, 2013; Ricard \& Pelletier, 2016; Tomás, Gutiérrez, Sancho, Chireac, \& Romero, 2016). Teachers' support is indispensable to create warmth and welcoming atmosphere that values students' contributions.

Overall, the present study reinforces the results obtained in a study on student engagement conducted in Colombia (Pineda-Báez et al., 2014) that pinpointed the need to foster an appropriate classroom climate so that students take active part in their educational process. In fact, a recent report on the Colombian education system also highlights that a crucial aspect to improve the quality of the educational experiences is to reduce top down teaching practices that hinder student engagement (OECD, 2016).

However, our results allow us to identify elements that play critical roles in the development of programs, strategies, or projects intended to strengthen school engagement. Additionally, future research should consider the need for teachers' professional development for guiding them in supporting school engagement and encouraging them to consider educational methodologies that support a positive school environment, particularly in terms of relations between them and their students.

Based on our results, programs could be better designed to help mitigate the risk factors that can contribute to children and adolescents dropping out of school. Consideration should be given to technology-mediated programs that are geared toward student interests and that motivate students to become more engaged. A recent review on the literature that has examined the connection between technologies and engagement reveals a positive relation between the two of them leading to more student investment (Schindler, Burkholder, Morad, \& Marsh, 2017). The next phase of a current project of this type involves designing digital resources focused on strengthening the school climate and school engagement to avoid dropout among seventh graders. Such digital educational materials can help students recognize their metacognitive abilities through identifying situations that reinforce the different forms of appropriating knowledge and by emphasizing the importance of active classroom participation.

Future studies should focus on the relationship between dropout rates and school engagement and could cover a larger number of schools and students. Larger studies of this kind should provide better understandings of the phenomenon that would, in turn, help improve existing and design better new programs that more successfully support students and their school communities.

\section{Acknowledgments}

This work was supported by the Dirección General de Investigación, Universidad de La Sabana and involved the academic units of Centro de Tecnologías para La Academia and Facultad de Educación [grant number CTA-27-2017].

\section{References}

Ackert, E. (2018). Segregation paradox? School racial/ethnic and socioeconomic composition and racial/ethnic differences in engagement. Social Science Research, 70, 144-162. https://doi.org/10.1016/j.ssresearch.2017.10.010

Alfonso, M., Bos, M., Duarte, J., \& Rondón, C. (2012). Panorama general de la educación en América Latina y el Caribe. In: M. Cabrol \& M. Székely (Eds.), Educación para la transformación (pp. 33-67). Banco Interamericano de Desarrollo. https://doi.org/10.18356/23ff8512-es

American Psychological Association. (1972). Ethical standards of psychologists. Washington, DC: American Psychological Association.

Appleton, J. J., Christenson, S. L., \& Furlong, M. J. (2008). Student engagement with school: Critical conceptual and methodological issues of the construct. Psychology in the Schools, 45, 369-386. https://doi.org/10.1002/pits.20303

Archambault, I., Janosz, M., Morizot, J., \& Pagani, L. (2009). Adolescent behavioral, affective, and cognitive engagement in school: Relationship to dropout. Journal of School Health, 79(9), 408-415. https://doi.org/10.1111/j.1746-1561.2009.00428.x

Awang-Hashim, R., Kaur, A., \& Noman, M. (2015). The interplay of socio-psychological factors on school engagement among early adolescents. Journal of Adolescence, 45, 214-224. https://doi.org/10.1016/j.adolescence.2015.10.001

Banco Interamericano de Desarrollo-BID. (2016). Avances y desafios en educación en América Latina y el 
Caribe. https://doi.org/10.18235/0000320

Bassi, M., Busso, M., \& Muñoz, J. S. (2015). Enrollment, graduation and dropout rates in Latin America: Is the glass half empty or half full? Economia. Journal of the Latin American and Caribbean Economic Association, 113-156. https://doi.org/10.2139/ssrn.2367706

Ben-David, Y., \& Ben-Ari, M. (2008). Fertile zones of cultural encounter in computer science education. The Journal of the Learning Sciences, 17, 1-32. https://doi.org/10.1080/10508400701793166

Bryant, V. C., Shdaimah, C., Sander, R. L., \& Cornelius, L. J. (2013). School as haven: Transforming school environments into welcoming learning communities. Children and Youth Services Review, 35(5), 848-855. https://doi.org/10.1016/j.childyouth.2013.02.001

Carbonaro, W., \& Workman, J. (2013). Dropping out of high school: Effects of close and distant friendships. Social Science Research, 42(5), 1254-1268. https://doi.org/10.1016/j.ssresearch.2013.05.003

Dolzan, M., Sartori, R., Charkhabi, M., \& De Paola, F. (2015). The effect of school engagement on health risk behaviours among High School Students: Testing the mediating role of self-efficacy. Procedia - Social and Behavioral Sciences, 205, 608-613. https://doi.org/10.1016/j.sbspro.2015.09.091

Dunne, M., \& Ananga, E. D. (2013). Dropping out: Identity conflict in and out of school in Ghana. International Journal of Educational Development. https://doi.org/10.1016/j.ijedudev.2012.04.005

Fernández-Zabala, A., Goñi, E., Camino, I., \& Zulaika, L. M. (2016). Family and school context in school engagement. European Journal of Education and Psychology, 9(2), 47-55. https://doi.org/10.1016/j.ejeps.2015.09.001

Fortin, L., Lessard, A., \& Marcotte, D. (2010). Comparison by gender of students with behavior problems who dropped out of school. Procedia - Social and Behavioral Sciences, 2(2), 5530-5538. https://doi.org/https://doi.org/10.1016/j.sbspro.2010.03.902

Fredricks, J. A., Blumenfeld, P. C., \& Paris, A. H. (2004). School engagement: Potential of the concept, state of the evidence. Review of Educational Research, 74, 59-109. https://doi.org/10.3102/00346543074001059

Gibbs, B. G., \& Heaton, T. B. (2014). Drop out from primary to secondary school in Mexico: A life course perspective. International Journal of Educational Development. https://doi.org/10.1016/j.ijedudev.2013.11.005

Gómez-Restrepo, C., Padilla, A., \& Rincón, C. J. (2016). Deserción escolar de adolescentes a partir de un estudio de corte transversal: Encuesta Nacional de Salud Mental Colombia 2015. Revista Colombiana de Psiquiaría, 45(S1), 105-112. https://doi.org/10.1016/j.rcp.2016.09.003

Gutiérrez, M., Tomás, J.-M., Romero, I., \& Barrica, J. M. (2017). Perceived social support, school engagement and satisfaction with school. Revista de Psicodidáctica (English Ed.), 22(2), 111-117. https://doi.org/10.1016/j.psicoe.2017.05.001

Henry K. L., Knight, K. E., \& Thornberry, T. P. (2012). School disengagement as a predictor of dropout, delinquency, and problem substance use during adolescence and early adulthood. Journal of Youth and Adolescence, 41(2), 156-66. https://doi.org/10.1007/s10964-011-9665-3

Jones J. M., Lee, L. H., Matlack, A., \& Zigarelli, J. (2018). Using sisterhood networks to cultivate ethnic identity and enhance school engagement. Psychology in the Schools, 55, 20-35. https://doi.org/10.1002/pits.22087

Kent, J., Jones, D., Mundy, M. A., \& Isaacson, C. (2017). Exploring contributing factors leading to the decision to drop out of school by Hispanic males. Research in Higher Education Journal, 32, 1-19. Retrieved from http://www.redi-bw.de/db/ebsco.php/search.ebscohost.com/login.aspx\%3Fdirect\%3Dtrue\%26db\%3Deric\% 26AN\%3DEJ1148943\%26site\%3Dehost-live

Krauss, S. E., Kornbluh, M., \& Zeldin, S. (2017). Community predictors of school engagement: The role of families and youth-adult partnership in Malaysia. Children and Youth Services Review, 73, 328-337. https://doi.org/10.1016/j.childyouth.2017.01.009

Kuh, G., Kinzie, J., Schuh, J., Whitt, E., \& Associates. (2005). Student success in college: Creating conditions that matter. San Francisco: Jossey-Bass. https://doi.org/10.1080/10668920600742093

Lawson, M. A., \& Lawson, H. A. (2013). New conceptual frameworks for student engagement research, policy, and practice. Review of Educational Research, 83(3), 432-479. https://doi.org/10.3102/0034654313480891

Montenegro, A. (2017). Understanding the concept of agentic engagement for learning. Colombian Applied 
Linguistics Journal, 19(1), 117-128. https://doi.org/10.14483/calj.v19n1.10472

Pascarella, E., \& Terenzini, P. (2005). How college affects students: Findings and insights from twenty years of research. San Francisco: Jossey-Bass

Pineda-Báez, C., Bermúdez-Aponte, J. J., Rubiano-Bello, A., Pava-García, N., Suárez-García, R., \& Cruz-Becerra, F. (2014). Compromiso estudiantil y desempeño académico en el contexto universitario colombiano. RELIEVE, 20(2), art 3. https://doi.org/10.7203/relieve.20.2.4238

Quin, D., Heerde, J. A., \& Toumbourou, J. W. (2018). Teacher support within an ecological model of adolescent development: Predictors of school engagement. Journal of School Psychology, 69, 1-15. https://doi.org/10.1016/j.jsp.2018.04.003

Ramos-Díaz, E., Rodríguez-Fernández, A., Fernández-Zabala, A., Revuelta, L., \& Zuazagoitia, A. (2016). Apoyo social percibido, autoconcepto e implicación escolar de estudiantes adolescentes. Revista de Psicodidáctica, 21(2), 339-356. https://doi.org/10.1387/revpsicodidact.14848

Raphael, L. M.; Pressley, M., \& Mohan, L. (2008). Engaging instruction in middle school classrooms: An observational study of nine teachers. The Elementary School Journal, 109(1), 61-81. https://doi.org/10.1086/592367

Reeve, J. (2012). A self-determination theory perspective on student engagement. In S. L. Christenson, A. L. Reschly, \& C. Wylie (Eds.), Handbook of research on student engagement (pp. 149-172). Boston, MA: Springer US. https://doi.org/10.1007/978-1-4614-2018-7_7

Reeve, J., \& Tseng, C.-M. (2011). Agency as a fourth aspect of students' engagement during learning activities. Contemporary Educational Psychology, 36(4), 257-267. https://doi.org/10.1016/j.cedpsych.2011.05.002

Reyes, M. R., Brackett, M. A., Rivers, S. E., White, M., \& Salovey, P. (2012). Classroom emotional climate, student engagement, and academic achievement. Journal of Educational Psychology, 104, 700-712. https://doi.org/10.1037/a0027268

Ricard, N. C., \& Pelletier, L. G. (2016). Dropping out of high school: The role of parent and teacher self-determination support, reciprocal friendships and academic motivation. Contemporary Educational Psychology, 44-45, 32-40. https://doi.org/10.1016/j.cedpsych.2015.12.003

Rodríguez, C., \& Sánchez, F. (2012) Armed conflict exposure, human capital investments, and child labor: Evidence from Colombia. Defence and Peace Economics, 23(2), 161-184. https://doi.org/10.1080/10242694.2011.597239

Rothman, L., Buliung, R., Howard, A., Macarthur, C., \& Macpherson, A. (2017). The school environment and student car drop-off at elementary schools. Travel Behaviour and Society, 9, 50-57. https://doi.org/10.1016/j.tbs.2017.03.001

Schindler, L. A., Burkholder, G. J., Morad, O. A., \& Marsh, C. (2017). Computer-based technology and student engagement: a critical review of the literature. International Journal of Educational Technology in Higher Education, 14(1), 1-28. https://doi.org/10.1186/s41239-017-0063-0

Schneider, C., \& Arnot, M. (2018). Transactional school-home-school communication: Addressing the mismatches between migrant parents and teachers' views of parental knowledge, engagement and the barriers to engagement. Teaching and Teacher Education, 75, 10-20. https://doi.org/10.1016/j.tate.2018.05.005

Schwartz, A. E., Stiefel, L., \& Wiswall, M. (2016). Are all schools created equal? Learning environments in small and large public high schools in New York City. Economics of Education Review, 52, 272-290. https://doi.org/10.1016/j.econedurev.2016.03.007

Sheard, J., Carbone, A., \& Hurst, A. J. (2010). Student engagement in first year of an ICT degree: staff and student perceptions. Computer Science Education, 20(1), 1-16. https://doi.org/10.1080/08993400903484396

Steinmayr, R., Weidinger, A. F., \& Wigfield, A. (2018). Does students' grit predict their school achievement above and beyond their personality, motivation, and engagement? Contemporary Educational Psychology, 53, 106-122. https://doi.org/10.1016/j.cedpsych.2018.02.004

Tomás, J. M., Gutiérrez, M., Sancho, P., Chireac, S. M., \& Romero, I. (2016). El compromiso escolar (school engagement) de los adolescentes: medida de sus dimensiones [School engagement among adolescents: Measurement of its dimensions]. Enseñanza \& Teaching, 34(1), 19-135. https://doi.org/10.14201/et2016341119135 
UNESCO. (2013). Situación educativa de América Latina y el Caribe: Hacia la educación de calidad para todos al 2015. Santiago de Chile: Oficina Regional de Educación para América Latina y el Caribe (OREALC/UNESCO). https://doi.org/10.15220/978-92-9189-198-6-sp

Veiga, F. H. (2013). Envolvimento dos alunos na escola: Elaboração de uma nova escala de avaliação [Student involvement in school: The development of a new evaluation scale]. International Journal of Developmental and Educational Psychology, 1(1), 441-450.

Wang, M. T., \& Fredricks, J. A. (2014). The reciprocal links between school engagement, youth problem behaviors, and school dropout during adolescence. Child Development, 85(2), $722-37$. https://doi.org/10.1111/cdev.12138

Wang, M. Te, Kiuru, N., Degol, J. L., \& Salmela-Aro, K. (2018). Friends, academic achievement, and school engagement during adolescence: A social network approach to peer influence and selection effects. Learning and Instruction, 58, 148-160. https://doi.org/10.1016/j.learninstruc.2018.06.003

Zimmerman, B. J., \& Cleary, T. J. (2006). Adolescents' development of personal agency. The role of self-efficacy beliefs and self-regulatory skill. In F. Pajares, \& T. Urdan (Eds.), Self-efficacy beliefs of adolescence (pp. 45-69). Mahwah, NJ: Information Age Publishing.

\section{Copyrights}

Copyright for this article is retained by the author(s), with first publication rights granted to the journal.

This is an open-access article distributed under the terms and conditions of the Creative Commons Attribution license (http://creativecommons.org/licenses/by/4.0/). 